\title{
SULTÕES E BANQUEIROS: a dominação financeira europeia no Império Otomano
}

\author{
Felipe Alexandre Silva de Souza*
}

\begin{abstract}
RESUMO: Pretendemos discutir a dominação europeia no Império Otomano durante a segunda metade do século XIX, recuperando o histórico da concessão de empréstimos por instituições governamentais e privadas francesas e britânicas a Constantinopla. Esses empréstimos contribuíram para o desenvolvimento de uma correlação de forças desfavorável ao governo otomano, que eventualmente foi obrigado a transferir a estrangeiros o controle direto de suas fontes de renda. Nossa intenção central é ressaltar como esse processo adveio não apenas da expansão planetária do modo de produção capitalista, mas também de questões internas ao Império Otomano, que recorreu aos empréstimos estrangeiros como fonte de recursos para executar projetos próprios.
\end{abstract}

PALAVRAS-CHAVE: Império Otomano; Empréstimos; Dominação estrangeira; Capital financeiro.

\section{Sultans and bankers: european financial domination in the Ottoman Empire}

ABSTRACT: We intend to discuss the european domination of the Ottoman Empire during the second half of the 19th Century, recovering the history of loans concessions to Constantinople by french and british private and governamental institutions. These loans contributed to the development of a very unfavourable forces correlation to the Ottoman Empire, which was eventually obligated to transfer the direct control os its revenues sources to foreign agents. Our aim is to emphasize how this process was composed not only by world wide expansion of the capitalist mode of production, but also by Ottoman Empire's internal questions, taking into consideration that the Ottoman government recurred to foreign loans as a resource to undertake its own project.

KEYWORDS: Ottoman Empire; Loans; Foreign domination; Finance capital.

\section{Sultanes y banqueros: la dominación finanicera europea en el Imperio Otomano}

RESUMÉN: Pretendemos abordar la dominación europea del Imperio Otomano durante la segunda mitad del siglo XIX, rememorando la historia de concesiones de préstamos a Constantinopla hechas por instituciones privadas y gobiernamentales británicas y francesas. Eses préstamos contribuyeron para el desarrollo de una correlacion de fuerzas desfavorable para el Imperio Otomano, que tuvo que transferir el control directo de sus fuentes de rendimiento para agentes extranjeros. Nuestra intención es enfatizar que ese proceso se formó no solamente por la expansión planetaria del modo de producción capitalista, pelo también por cuestiones internas, una vez que el gobieno otomano busco a los préstamos como una fuente de fondos para ejecutar proyectos propios.

PALABRAS CLAVE: Imperio Otomano; Préstamos; Dominación extranjera; Capital financiero.

\footnotetext{
*Mestre em Ciências Sociais pela Universidade Estadual Paulista Júlio de Mesquita Filho e Bacharel em Comunicação Social: Habilitação em Jornalismo pela Universidade Estadual de Londrina (UEL). Contato: Universidade Estadual Paulista Júlio de Mesquita Filho, Campus Marília, Faculdade de Filosofia e Ciências Humanas. Rua Gal Osório, 52, CEP; 17502-570 Marília - SP, Brasil. E-mail:felipedesouza1988@gmail.com.
} 


\section{Introdução}

Em 1854, diante do fardo crescente que a Guerra da Crimeia (1853-1856) estava se tornando para o tesouro do Império Otomano, o governo do Sultão Abdulmecid I tomou uma decisão inédita: contraiu seu primeiro empréstimo estrangeiro, junto ao banco privado inglês Dent, Palmers \& Co, no valor de três milhões de libras esterlinas a juros anuais de seis por cento, um acordo enfaticamente encorajado pelo governo britânico, aliado do sultão na guerra. Os tributos provenientes do Egito, então uma província otomana, foram utilizados como garantia e eram depositados pelo próprio quediva egípcio ${ }^{1}$ diretamente no Banco da Inglaterra $^{2}$, que atuou como fiador do empréstimo (BIRDAL, 2010; ELDEM, 2005). Ao longo dos próximos vinte anos, o Império contraiu 14 acordos de empréstimos adicionais junto a agentes europeus. Em 1876, incapaz de pagar as dívidas, a Sublime Porta declarou falência, acelerando um processo que culminou em sua submissão aos interesses financeiros europeus e a perda do controle sobre suas próprias fontes de renda.

Segundo Birdal (2010), esse processo tende a ser visto pelos estudiosos como pouco mais que um exemplo do imperialismo ocidental, com as potências europeias pressionando o sultanato em direção ao endividamento. Essa visão é comum entre autores filiados a perspectivas de esquerda, tais como os teóricos do sistema-mundo. $\mathrm{O}$ artigo de Wallerstein, Decdelí e Kasaba, The incorporation of the Ottoman Empire into the world-economy (2004), por exemplo, considera o endividamento otomano como um elemento crucial da subsunção do Império aos imperativos da expansão em escala planetária do modo de produção capitalista.

Em suas bases, essa visão está correta. Como examinaremos a seguir, uma das consequências da dívida pública otomana foi de fato uma maior abertura de espaço para que grupos capitalistas e governamentais europeus pudessem mobilizar os recursos naturais e humanos dos territórios do Império na direção da acumulação de capital. O endividamento de Constantinopla não foi de forma alguma um incidente isolado. A partir da segunda metade da década de 1870 e principalmente durante os anos 1880, muitos governos de países devedores enfrentaram problemas graves de dívida externa e eventualmente tiveram de concordar com novos contratos com seus credores para sanar o débito. Comumente esses processos estabeleciam correlações de força extremamente desfavoráveis para os países devedores. Em alguns casos, os credores ficavam satisfeitos com certas alterações institucionais que asseguravam o pagamento de seus empréstimos e ofereciam oportunidades para avançar em 
seus interesses políticos e econômicos. Em situações mais extremas, como a otomana, os credores adquiriam controle direto sobre as fontes de renda dos países devedores.

Todavia, esse tipo de abordagem, ainda é, ainda que correto em diversos aspectos, redutor e binário, por tender a enfatizar demasiadamente as dinâmicas dos países considerados centrais ou imperialistas, em detrimento dos países tidos como dominados, periféricos ou satélites. Isso se desdobra em uma tendência a desconsiderar as dinâmicas particulares dos países periféricos, criando-se a imagem de países imperialistas onipotentes em contraposição a nações dominadas totalmente passivas, uma vez que perdemos nuances que não são apenas detalhes, mas sim elementos importantes para esses processos. Essa abordagem também dá margem para outra tendência grave: a da abstração a tal nível que são tomadas como agentes históricos categorias que, embora fundamentais para o entendimento de muitos processos históricos, na maioria dos trabalhos aparecem como entidades desprovidas de concretude, tais como o capital, o imperialismo, a burguesia, o proletariado, etc.

Visando contornar minimamente as tendências descritas acima, partimos do pressuposto de Marc Bloch (2015), segundo o qual o estudo da história tem como objeto principal os homens no tempo ${ }^{3}$, e da concepção de Edward Palmer Thompson (sd) segundo a qual a História é feita pelas relações entre homens concretos, dotados de relativa autonomia de pensamento, associação e ação, pressionados pelas condições sociais criadas pelas relações de outros homens ao seu redor, e ao mesmo tempo partícipes dessas condições. Nesse sentido, buscaremos, por meio de uma revisão bibliográfica, fazer o resgate histórico da série de concessões europeias de empréstimos ao sultanato de Constantinopla buscando salientar o contexto social interno que se desenvolvia no Império Otomano no fim do século XIX e o papel ativo de seus governantes nesse processo.

Como é inevitável quando lidamos com processos históricos complexos e relativamente longos em espaços reduzidos, tais como este texto, eventualmente cairemos em simplificações excessivas. Não obstante, julgamos o espaço suficiente para discutir um aspecto da dominação europeia no Império Otomano sem que os "dominados" - neste caso, os governantes otomanos ${ }^{4}$ - apareçam como agentes passivos diante de forças externas onipotentes, recuperando a dialética entre o sultanato e os diversos grupos capitalistas europeus. 


\section{Interesses capitalistas frente ao declínio do sultanato de Constantinopla}

Como já mencionado, a dominação financeira europeia no Império Otomano foi parte da expansão mundial, a partir do século XVI, das ações das classes capitalistas europeias, que intensificaram as interações entre a Europa Ocidental e os povos asiáticos, africanos e americanos. Dentre essas relações, foram notáveis os intercâmbios e conflitos políticos, econômicos e culturais entre europeus e o mundo islâmico, do qual a Porta de Constantinopla era um dos núcleos políticos principais, juntamente ao Império Mogol no subcontinente indiano e o Sublime Estado da Pérsia. A força do Império Mogol impressionava os navegadores ingleses, portugueses e franceses que estabeleciam postos de comércio no litoral da Índia ao longo dos séculos XVII e XVIII (KIERNAN, 1969). Todavia, esse império veio a sucumbir, graças a uma combinação de disputas internas e à conquista do subcontinente pelos britânicos. A Grande Revolta de 1857-1858 — a última tentativa das velhas classes dominantes de reverter a dominação britânica - assinalou o fim definitivo da dinastia Mogol e a consolidação da submissão da Índia ao Império Britânico (PANIKKAR, 1969). Paralelamente, a Pérsia era comandada, no século XIX, pela dinastia sunita Qajar, e se encontrava bastante debilitada, pressionada a oeste pelos otomanos e a norte e leste pelos uzbesques e turcomanos, além de sofrer internamente com a falta de controle sobre algumas minorias tribais (KIERNAN, 1969). Apesar dos interesses britânicos, e de perder partes de seu território para os russos e britânicos (KIERNAN, 1982), a Pérsia conseguiu sobreviver até a chegada do século XX. O único outro estado muçulmano a sobreviver à derrota generalizada para os europeus durante todo o século XIX foi o Império Otomano (LEWIS, 2010), sob o qual nos deteremos agora.

Comecemos por ressaltar que estado otomano era organizado politicamente de forma centralizada. Mais do que um soberano todo-poderoso, o sultão também era o principal proprietário de cerca de $90 \%$ das terras dentro do Império ${ }^{5}$, e não as concedia em forma de propriedade. Essas terras constituíam a principal fonte de renda do Estado, cultivadas por meio do trabalho servil e gerenciadas pelos sipahis, representantes do Sultão encarregados de organizar o cultivo e coletar impostos dos camponeses (PALMER, 2014; WOLF, 2009). A exploração fiscal era uma das atividades principais do Estado Otomano, e uma boa forma de se distinguir, grosso modo, as principais classes sociais do Império é verificar a posição que pessoas e grupos ocupavam em relação aos impostos. Os Osmanlilar eram a classe dirigente, aglutinados em altas funções administrativas e religiosas, e sustentados pelos impostos, de cuja cobrança eram isentos. Os rayah eram os súditos, que pagavam os impostos; eram heterogêneos, compostos majoritariamente por camponeses e artesãos, mas também — em 
escala muito menor - por grupos privados economicamente poderosos, como banqueiros e grandes mercadores (ANDERSON, 1974).

Camponeses, artesãos e todos os que trabalhavam na produção estavam submetidos a restritos códigos que regulamentavam todos os aspectos de suas atividades, desde os métodos de produção ${ }^{6}$ até as margens de lucro permitidas ${ }^{7}$. Os mercadores eram menos sujeitos a esses complexos regulamentos e permitidos a acumular capital, embora necessitassem da autorização governamental para atuar. No contexto otomano, eram considerados mercadores os grandes comerciantes que lidavam com importação e exportação de grandes quantidades de produtos $^{8}$. Organizados em corporações de comércio, sua atividade era essencial, pois eram eles que possibilitavam a circulação de matérias primas, alimentos e outros produtos essenciais dentro do Império, bem como suas transações com a Europa (INALCIK, 1969).

Quanto às atividades industriais significativas, estavam concentradas principalmente nas cidades de Bursa e Edirne (antiga Adrianópolis), e também eram fortemente reguladas pelo Estado. A produção se concentrava na seda e outros têxteis, embora a indústria bélica também mereça destaque, uma vez que o Estado tinha a seu serviço várias empresas privadas para equipar o exército. Constantinopla, a capital e maior cidade, se destacava menos pela produção e mais pela concentração de mercadores e especuladores financeiros ${ }^{9}$ (INALCIK, 1969; ANDERSON, 1974).

A partir do século XVI, as relações que acabamos de descrever começaram a se fragilizar, em um longo processo que posteriormente veio a ser conhecido como declínio do Império Otomano. Evidentemente trata-se de um processo não-linear e multicausal, do qual salientaremos alguns elementos pertinentes para nossa discussão. Primeiramente, é necessário ter em mente que a coesão do governo se devia em grande medida da aquisição contínua de novos territórios por meios militares. Segundo Lewis (2010), o estado otomano surgiu no final do século XIII, na fronteira entre o Islã e a Cristandade, na Anatólia, Seus soberanos usavam o título de chefe dos ghazi, como eram chamados os guerreiros de fronteiras. Os ghazi se viam como um instrumento de Deus para limpar a terra do politeísmo e dos infiéis. Nessa guerra santa, a Europa era vista pelos otomanos como uma terra árida e primitiva, para as quais era sua missão levar a religião do Islã, e o Império manteve, nos séculos seguintes à sua fundação, tal senso de missão sagrada. O fim da expansão trouxe mudanças profundas na dinâmica interna da Sublime Porta (LEWIS, 2010). Uma das consequências foi a redução do corpo militar otomano, o que lançou no império uma massa de novos desempregados que em sua maioria não encontraram novas atividades. Ao mesmo tempo, a falta de novas terras, aliada ao conservadorismo técnico oficial que tolhia os produtores, acarretou em baixas 
cumulativas na produção e nas receitas, levando o sultanato, ao longo dos dois séculos seguintes, a intensificar da exploração do trabalho no campo para compensar a perda de receitas, além de implementar numerosos novos impostos (ANDERSON, 1974).

Nesse ínterim, no final do século XVIII, alguns grupos industriais capitalistas europeus, principalmente de origem francesa e inglesa, estabeleciam uma correlação de forças cada vez mais favorável em relação a outros grupos de classe de seus próprios países, adquirindo maior capacidade de pressionar as instâncias governamentais em favor de seus interesses próprios. Alguns desses grupos enxergavam a população e os recursos naturais do Império Otomano como possíveis meios de acumulação de capital. Um indicativo disso é o fato de que as transações comerciais entre Império Otomano e França quadruplicaram na segunda metade do século XVIII, especialmente a exportação otomana de cereais e algodão. No início do século XIX, os industriais franceses do setor têxtil tinham no Império Otomano sua principal fonte de matérias primas (WALLERSTEIN, 2011). O depoimento de um membro da Câmara de Comércio de Marselha, em 1792, sinaliza o peso crescente da Porta Islâmica para as fábricas francesas: “[...] o destino do Levante é ser uma fonte de fornecimento [de matérias-primas] para a indústria francesa" (MASSON, apud WALLERSTEIN, 2011, p.141). Ao longo do século XIX, os ingleses e (em menor medida) os austríacos paulatinamente ocuparam o lugar dos franceses no posto de principais parceiros comerciais. A maior parte do algodão plantado na Anatólia passou a ser destinada à Inglaterra, bem como os grãos cultivados nos Balcãs (WALLERSTEIN, 2011).

Ao mesmo tempo, o Império Otomano passou a importar uma massa crescente de manufaturados europeus, em termos altamente desfavoráveis e à custa da produção local. Se ao longo do século XVIII a produção otomana de tecidos de seda e fios de algodão era forte e capaz de competir nos mercados europeus, no século seguinte o avanço tecnológico proporcionado pelas novas máquinas de fiação inglesas e a implementação de várias medidas protecionistas na Europa rapidamente tiraram qualquer possibilidade de competitividade para os produtos otomanos, inclusive dentro dos limites do próprio Império. Apesar de várias tentativas protecionistas, a começar por algumas medidas implementadas pelo sultão Salim III em 1793 e 1794, o governo otomano, desgastando-se cada vez mais com tensões internas, não conseguiu barrar a entrada de produtos europeus em seu território. Um marco dessas relações foi o Tratado Balta Liman ${ }^{10}$, elaborado pelos ministros de relações exteriores da Inglaterra e do Império Otomano e assinado em 1838, que bania os monopólios autóctones e permitia aos homens de negócios ingleses livre acesso aos mercados otomanos ${ }^{11}$ (HOURANI, 2006). Em meados do século XIX, a atividade manufatureira otomana, inclusive nos dois polos 
principais já mencionados, Bursa e Erdine, havia declinado vertiginosamente, e o Império passou, majoritariamente, a exportar matérias primas para depois comprá-las de volta na forma de manufaturados (FARLEY, apud WALLERSTEIN, 2011).

Os monopólios eram uma das fontes de impostos do Estado, e seu enfraquecimento reduziu a arrecadação. Por conta disso, cada vez mais os empréstimos eram vistos na cúpula governamental como uma saída fácil, em curto prazo, para equilibrar as finanças (WALLERSTEIN, 2011). Já em 1775 o Estado passou a tomar dinheiro emprestado do poderoso consórcio financeiro otomano conhecido como os Banqueiros de Gálata ${ }^{12}$. Esses financistas eram a principal fonte de onde o governo podia tomar dinheiro emprestado, e tinham na folha de pagamento funcionários infiltrados entre os burocratas do sultão, com a função de fazer pressões e articulações dentro do governo para garantir que os empréstimos fossem pagos o quanto antes, não importando o estado de déficit no qual se encontrasse o Estado. Birdal (2010) aponta que a decadência do Império foi extremamente lucrativa para os Banqueiros de Gálata e seus colaboradores no governo. Na medida em que cresceram as necessidades financeiras do Império, o sultanato se tornava cada vez mais dependentes desses banqueiros, que cobravam juros altíssimos ${ }^{13}$. Cumpre notar que, embora esses empréstimos fossem considerados domésticos, o capital financeiro esteve consideravelmente presente. Os Banqueiros de Gálata tinham conexões com bancos estrangeiros, além de filiais instaladas nas principais capitais europeias. Essas conexões eram usadas para tomar dinheiro emprestado do exterior e passá-lo para o governo como um novo empréstimo (BIRDAL, 2010).

O Estado não demorou a contrair um considerável montante de dívidas. Estas começaram a ser liquidadas em 1792, mas os danos causados pela invasão francesa no Egito, em 1798, fizeram com que o governo entrasse em uma nova rodada de empréstimos domésticos. Em 1812 o pagamento da dívida externa consumiu $25 \%$ do orçamento anual do governo (HANIOĞLU, 2008). Após a invasão napoleônica, alguns administradores cogitaram contrair empréstimos estrangeiros, mas o primeiro acordo desse tipo só seria feito, como veremos, na segunda metade do século XIX. Empréstimos estrangeiros eram tradicionalmente vistos como humilhantes e degradantes pela cúpula dirigente otomana e, além disso, no começo do século XIX era relativamente difícil encontrar governos ou grupos privados europeus dispostos a conceder empréstimos massivos (OZEKICIOGLU e OZEKICIOGLU, 2010). 


\section{De empréstimo em empréstimo, o Império Otomano perde sua autonomia financeira}

Outro elemento agravante para o sultanato foi o crescimento demográfico a partir do século XVII, somado à redução da disponibilidade fundiária, o que acarretou no crescimento do contingente de camponeses sem terra, contribuindo para a eclosão de conflitos sociais e para o aumento do banditismo (ANDERSON, 1974). Incapaz de mitigar essas tensões, o governo central via sua autoridade progressivamente contestada pela crescente autonomia de seus representantes locais, resultando no surgimento de vários potentados relativamente independentes de Constantinopla. Meio a essa tendência centrífuga e ao aumento das tensões sociais, vários grupos internos procuraram, no século XIX, aproveitar a situação para forjar alianças com os diversos governos e grupos privados europeus que se faziam cada vez mais presentes, com o intuito de acumular forças para defender seus interesses frente ao sultanato. Esses grupos iam desde governadores de províncias que buscavam maior autonomia em relação à capital para executar programas socioeconômicos próprios, como Muhammad Ali (governador do Egito entre 1804 e 1848), até vários grupos nacionais que buscavam total independência do Império, tais como a Hetaria, uma sociedade secreta fundada por intelectuais e mercadores gregos fora do Império Otomano, e que acabou liderando a guerra de independência grega (1821-1832); além de diversos outros movimentos de independência ao longo da Rumélia ${ }^{14}$.

Evidentemente, não apenas simplificamos um processo de longa duração, como também passamos ao largo de vários elementos importantes e marcantes diferenças regionais no que tange ao declínio otomano. O que fizemos foi esboçar alguns fenômenos que contribuíram para aquilo se tornou, no início do século XIX, uma das características fundamentais da desintegração do Império Otomano: a descentralização da autoridade. Se no começo desse século o território imperial oficialmente se alongava do Iêmen à Argélia, da Bósnia ao Cáucaso e da Eritreia à Basra, abarcando uma vasta área habitada por 30 milhões de pessoas, na prática, o governo de Constantinopla tinha alcance para manter o controle efetivo de apenas nas províncias centrais da Anatólia e na Rumélia. O restante dos domínios do sultanato já exibia uma ampla variedade de padrões administrativos, com governadores locais apoiados exércitos privados e cada vez mais autônomos. As regiões mais distantes do império, como a África e a Península Arábica, eram comandadas por tribos em disputa (HANIOĞLU, 2008).

A situação do Império Otomano era acompanhada de perto não apenas pelos grupos capitalistas que tinham interesse na região, mas também pelos meios diplomáticos europeus. Desde a derrota do projeto expansionista de Napoleão Bonaparte, a reorganização do mapa 
político da Europa no Congresso de Viena e a formação da Santa Aliança (Rússia, Prússia e Áustria), em 1815, o continente europeu passou boa parte do século XIX sem assistir a guerras envolvendo os países à época chamados "Grandes Potências". No entanto, a possibilidade de conflito bélico por conta de interesses conflitantes entre diversos grupos econômicos e projetos de Estado desses países sempre esteve subjacente, e o declínio do Império Otomano era justamente um dos pontos potencialmente mais explosivos das discussões diplomáticas da época. A crescente incapacidade do sultanato em controlar seu território era vista de forma promissora por diversas forças políticas e econômicas de origem inglesa, francesa, austríaca, russa e, depois de 1871, alemã - todos eles visando executar suas agendas de natureza geralmente estratégica e econômica (HOBSBAWM, 2006).

Às voltas com pressões externas (das quais necessitavam proteção) que se cruzavam com tensões endógenas, os sultões e seus funcionários começaram a considerar a necessidade de reformas políticas, administrativas e econômicas para recuperar o Império. Na década de 1820, o sultão Mahmud II e um pequeno grupo de altos funcionários conseguiram empreender uma ação decisiva voltada principalmente para a uma centralização do poder. Por meio da criação de um novo e melhor treinado exército, seria possível recuperar paulatinamente o controle direto sobre algumas das províncias na Europa, Anatólia, Iraque, Síria e Trípoli. Além disso, pretendia-se reorganizar o governo, como ficou claro no Decreto de Gülhane ${ }^{15}$, emitido em 1829, sobre bases com certa inspiração europeia, estabelecendo a igualdade jurídica entre os súditos, uma burocracia conciliar e um governo da lei (HOURANI, 2006).

Não obstante, esse grande projeto demandava recursos financeiros que o estado não possuía. Owen (2005) aponta que na década de 1850, tal era a situação do Império que a saída mais fácil seria a abertura para empréstimos estrangeiros. Além da gigantesca brecha entre gastos e arrecadação, o custo da manutenção de um exército grande o bastante para garantir a recentralização e assegurar a sobrevivência do estado, e sua constante atualização com armamentos modernos exigia mais do que os recursos locais podiam oferecer, o que se agravava com o fato de que a maioria das fábricas militares otomanas havia entrado em colapso, e o rápido avanço tecnológico europeu significava que armamentos cada vez mais caros teriam de ser importados.

Concomitantemente, outros grupos capitalistas — os financistas - se tornavam cada vez mais importantes na Europa Ocidental, em grande parte devido a mudanças nas correlações de força e no próprio patamar de acumulação de capital entre as classes dominantes europeias, principalmente na França e na Inglaterra. $\mathrm{O}$ desenvolvimento das forças produtivas e da circulação de mercadorias, principalmente por conta da Revolução 
Industrial, havia gerado uma grande monta de capital ocioso, que primeiramente foi investido no próprio território europeu. Na Grã-Bretanha, por exemplo, investiu-se em obras de infraestrutura, especialmente na malha ferroviária, que já havia revelado se não apenas de grande eficiência logística adequada ao nível de desenvolvimento industrial da época, mas também um lucrativo alvo de investimentos. Todavia, no final da década de 1840, essas obras se mostraram insuficientes para absorver todo o capital excedente ${ }^{16}$. "O mais óbvio escoadouro disponível que havia para esse excedente de capital era o investimento no exterior [...].” (HOBSBAWM, 2014, p.103). Nessa época foram fundadas várias instituições financeiras com o objetivo de canalizar parcelas de capital excedente em investimentos no exterior.

O primeiro empréstimo estrangeiro contraído pelo Império Otomano faz parte do contexto da Guerra da Crimeia (1853-1856). A “Questão Oriental” era um grande ponto de tensão entre os governos russo e inglês. Os russos tinham como principal objetivo conquistar o controle dos estreitos entre a Europa e a Ásia Menor (pertencentes ao sultanato), que condicionavam seu acesso ao Mediterrâneo. Os estrategistas do governo inglês tinham como prioridade proteger suas colônias no subcontinente indiano de qualquer tentativa de aproximação russa. Por isso, desde 1830 Constantinopla contava com apoio diplomático britânico, que tinha interesse em manter o Império Otomano minimamente intacto, já que este se erguia como um anteparo ao crescimento territorial da Rússia na Ásia Central (HOBSBAWM, 2006; LESSA, 2005). Em 1853, com o subterfúgio de defender monges ortodoxos russos em uma querela com religiosos franceses acerca da precedência na guarda dos lugares sagrados em Jerusalém, o exército do czar Nicolau I invadiu os principados otomanos da Moldávia e de Wallachia, no Danúbio ${ }^{17}$. O objetivo econômico subjacente era acessar o Mediterrâneo e seus circuitos de comércio. A diplomacia inglesa se aliou a Constantinopla para impedir danos irreversíveis ao Império Otomano e para assegurar o controle estratégico dos estreitos de Bósforo e Dardanelos (LESSA, 2005).

Os custos adicionais gerados pela guerra finalmente levaram Abdulmecid I a autorizar um empréstimo estrangeiro. Em 1854, as fontes de empréstimo doméstico haviam se tornado inviáveis. As taxas cobradas pelos Banqueiros de Gálata haviam então ultrapassado os quinze por cento. Em contrapartida, o empréstimo disponibilizado pelo banco Dent, Palmers \& Co. era mais atrativo, trazendo uma taxa de juros de 7,9\% (BIRDAL, 2010). Contudo, a Porta recebeu de fato pouco mais da metade do valor nominal de três milhões de libras do empréstimo, devido às várias comissões pagas a avalistas e demais intermediários da transação. A entrada do Banco da Inglaterra como fiador se explica pelo interesse do governo 
britânico em manter o Império Otomano forte o suficiente para dificultar as investidas russas. Segundo Palmer (2014), grande parte desse primeiro empréstimo foi gasta em áreas não relacionadas à guerra, tais como a manutenção da nova moradia do sultanato, o Palácio de Dolmabahçe, cujas despesas anuais consumiam cerca de dois milhões de libras esterlinas.

Em 1855, foi contraído um novo empréstimo, de cinco milhões de libras esterlinas, junto à Rothschild \& Sons, banco da família de financistas judeus de origem alemã então baseada em Londres (ELDEM, 2005). Os governos francês e inglês aceitaram o papel de fiadores, sob a condição de que os recursos fossem gastos em finalidades relacionadas à guerra e que sua utilização fosse supervisionada por um representante inglês e um francês condição que, devido à resistência do sultão, não chegou a ser atendida (PALMER, 2014; AL, 2009).

O Império teve muitas dificuldades em pagar os empréstimos. Depois de fortes tensões com a Porta, seus credores solicitaram que os governos francês e britânico interviessem na situação pressionando pelo pagamento, mas eles se recusaram. Todavia, em 1858, foi contraído um terceiro empréstimo, novamente junto à Dent, Palmer \& Co., no valor de oito milhões de libras, sem que nenhum governo europeu entrasse como fiador (AL, 2009; ELDEM, 2005).

Parte do dinheiro desses empréstimos foi empregada para melhorar as comunicações do Império - um elemento essencial para o projeto de recentralização. Foram feitos alguns investimentos em redes ferroviárias; na Rumélia, uma linha estratégia ligando Varna ao Danúbio foi iniciada em 1856 e, em seguida, uma linha pelo vale de Menderes, no sudeste da Anatólia, para transporte de produtos agrícolas até o porto de Esmirna. Também se investiu em estradas para o tráfego postal, e principalmente no telégrafo com fio. Antes da morte do Abdulmecid I, em junho de 1861, havia cabos ligando Constantinopla, Bucareste, Belgrado e Salônica, Üsküdar e Bagdá. O telégrafo era considerado pelo sultão como um elemento que promovia a coesão e a unidade do Império, por facilitar a comunicação do governo central com os governadores das províncias mais distantes, permitindo consequentemente maior controle (PALMER, 2014).

No início da década de 1860, o sultão ainda conseguia impedir que agentes de governos estrangeiros passassem a supervisionar as finanças do Império, em parte devido a sua própria persistência e em parte devido a dissensões entre os próprios países europeus a respeito de como tal empreitada seria realizada. Somando-se à dificuldade do pagamento dos empréstimos e à falta de fiscalização, em 1862, os governos francês e britânico recusaram o pedido do sultão Abdulaziz para fiarem um novo empréstimo. O Império, envolto em seu 
dispendioso projeto de recentralização e tentando conter suas variadas tensões políticosociais, não mais conseguia atrair investidores europeus privados (ELDEM, 2005). Nesse contexto, o Grão Vizir ${ }^{18}$ de Abdulmecid, Fuad Paxá, liderou uma série de reformas administrativas com o intuito de recuperar a credibilidade do governo frente a investidores internos e externos. Dentre as medidas tomadas, destaca-se o estabelecimento do Banco Imperial Otomano (BIO) em 1863. Embora fosse considerado um banco estatal, e desempenhasse todas as atribuições de um banco central - emissão de moeda, definição de políticas monetárias, a tarefa de administrar a estabilidade monetária, etc —, o BIO era controlado por um consórcio financeiro anglo-francês, e todos os seus funcionários de alto escalão, assim como a maioria de seus acionistas, eram estrangeiros (BIRDAL, 2010).

O envolvimento do governo na administração do banco foi uma das grandes questões durante as negociações [de seu estabelecimento]. Seu papel foi reduzido ao mínimo, como uma forma de angariar confiança nos mercados financeiros europeus. [...] Logo, a Porta era obrigada a aceitar que seus representantes desempenhassem um papel pouco maior do que assegurar a presença de um elemento otomano na hierarquia do banco. O governo também teria a autoridade de nomear um nazir (ministro) para propósito de inspeções e um muhasebeci (contador) para supervisionar as operações financeiras entre o banco e o tesouro, mas não tomaria parte de fato na administração do banco. (BIRDAL, 2010, p.33).

Segundo Hourani (2006), o Império Otomano contraiu, entre 1854 e 1879, um total nominal de empréstimos no valor de 256 milhões de libras turcas ${ }^{19}$, mas recebeu apenas 139 , o resto sendo descontado em forma de encargos. Um ano particularmente crítico foi 1874 , quando o pagamento da dívida externa consumiu 55\% do orçamento anual (CHOTZIDIS, s/d). Nesse ano, o sultanato tomou medidas drásticas que fragilizaram a já combalida autonomia financeira do Império:

\footnotetext{
Para melhorar a credibilidade do orçamento Otomano, o governo estabeleceu uma comissão para controlar e aprovar o orçamento de 1874-75. A comissão era formada por funcionários do estado, banqueiros e diretores dos principais estabelecimentos financeiros em Istambul. Dos treze membros da comissão, apenas três eram funcionários do governo. Todo o resto era composto por figuras proeminentes da comunidade financeira de Istambul, alguns dos quais eram muito conhecidos nos mercados financeiros europeus [...]. No que dizia respeito aos negócios financeiros domésticos, eram justamente essas as pessoas que precisavam ser convencidas de que o governo iria eliminar o déficit orçamentário. (BIRDAL, 2010, p.36).
}

Outra medida governamental foi a consolidação do BIO como banco estatal. A partir de então, toda a arrecadação de impostos do Império deveria ser depositada nas filiais do BIO, que também se tornou encarregado de fazer todos os pagamentos em nome do governo, inclusive os referentes às dívidas. Essas medidas fizeram com que o sultanato conseguisse um novo empréstimo no montante de 40 milhões de libras esterlinas, nos mercados britânico e 
francês, a juros de 11,5\%, os mais altos na história do Império Otomano até então. Em 1875, uma série de epidemias e enchentes e os resultados pífios das colheitas obrigaram o governo a desviar recursos da importação de armamentos para programas de prevenção da fome endêmica, e, consequentemente, a pleitear empréstimos adicionais. Devido à dificuldade em conseguir empréstimos externos, o sultanato se viu obrigado a novamente recorrer aos Banqueiros de Gálata, especialmente a partir de 1877, quando o Império entrou em guerra com a Rússia e teve de arcar com novos gastos.

Em 1876, a administração de Abdulhamid II decretou falência. Os Banqueiros de Gálata e o BIO, sob a grande influência de acionistas franceses e britânicos, conseguiram chegar a um acordo com o governo. Em novembro de 1879, por meio de decreto, o sultão cedeu a esses credores o controle de seis importantes fontes de renda do Império - os monopólios do sal, tabaco, seda, da pesca, bebidas e os impostos do selo. Isso significava que, na prática, a arrecadação de impostos provenientes de tais atividades seria encaminhada diretamente aos grupos financeiros credores do Império, que decidiriam a aplicação do montante. Para administrar esses recursos, foi criada a Administração das Seis Contribuições Indiretas, sob a chefia de um britânico, Hamilton Lang (CHOTZIDIS, s/d).

A partir de Constantinopla, Lang organizou uma eficiente infraestrutura de filiais administrativas no território do Império para coletar os pagamentos. Desde o início o sistema se revelou eficiente, mas os credores europeus, principalmente os britânicos e franceses, aumentaram a pressão sobre o sultanato nos anos seguintes. No fim de 1879, uma comissão internacional elaborou um relatório técnico a respeito da situação financeira da Sublime Porta e um plano de reorganização, e os apresentou ao sultanato, determinando que o débito nominal deveria ser reduzido em $35 \%$. Por outro lado, o receio cada vez maior da expansão do Império Russo fez com que as potências europeias hesitassem em cobrar toda a dívida externa otomana, calculando que uma repentina retirada de uma grande soma financeira poderia colocar os otomanos à beira do colapso, situação que poderia ser proveitosa para os russos. Por isso, foi criada uma comissão internacional permanente para administrar a dívida otomana. A presença de potências estrangeiras no controle das finanças otomanas fortaleceu a confiança dos credores internacionais na segurança de investimento, e isso afetou as taxas de juro, que se tornaram relativamente baixas (CHOTZIDIS, s/d).

No dia 20 de dezembro de 1881, Abdulhamid II baixou o Decreto de Muharrem, com vistas a regular as dívidas interna e externa do Império e - principalmente - criar a instituição conhecida como Administração da Dívida Pública Otomana (OPDA), para facilitar a coordenação entre os credores do Império, unificando o total das dívidas otomanas em 
quatro categorias, como uma forma de conciliar os interesses de diferentes credores e facilitar a administração (BIRDAL, 2010). Oficialmente, tratava-se de um departamento do Ministério Otomano das Finanças e a este subordinado, mas na prática a OPDA funcionava como uma seção independente. Era comandada pelo Concílio Administrativo, formado por sete representantes dos credores, de acordo com suas nacionalidades - um era responsável pelos credores belgas, ingleses e holandeses, cinco pelos franceses, alemães, austríacos e otomanos, e o último era um membro do $\mathrm{BIO}$, que representava os credores que detinham o controle da Administração das Seis Contribuições Indiretas (CHOTIZIDIS, s/d).

Segundo Quataert (2005), a OPDA não tardou a se tornar uma vasta burocracia autônoma dentro da burocracia otomana, chegando a empregar mais de cinco mil funcionários por todo o Império. Grosso modo, esses funcionários tinham como tarefa coletar impostos no interior do Império e transferi-los para os credores europeus. Para isso, a OPDA abriu escritórios de coleta de dívida em todas as cidades de médio e grande porte, e trabalhou em sintonia com o BIO: tudo que a OPDA recolhia era depositado nas filiais do Banco Imperial. A PDA possuía, segundo Birdal, duas dimensões principais:

Para os credores, a OPDA representava um esforço cooperativo para assegurar o pagamento dos empréstimos estrangeiros e para desenvolver um mecanismo de monitoramento para futuros investimentos diretos e indiretos no Império. Para o Império Otomano, o estabelecimento da OPDA proveu um instrumento para se comprometer de forma confiável com os termos especificados nos contratos de empréstimo e com a proteção do investimento estrangeiro no Império. Esse comprometimento permitiu ao governo otomano aumentar o acesso aos mercados estrangeiros de capital a taxas de juros mais baixas, e encorajar investimentos estrangeiros diretos. (BIRDAL, 2010, pp.64/65)

Encerrando nosso resgate histórico, mencionaremos o elemento que, segundo nossa avaliação, expressa de forma mais clara a magnitude da influência de agentes financeiros estrangeiros no Império: a tomada de controle, por parte desses agentes, de parcelas importantes do processo produtivo otomano. Esse controle se deu por intermédio da OPDA, que ultrapassou a esfera da coleta e administração de recursos ao criar subdivisões para interferir nos principais setores produtivos do Império - traçando metas de inovações tecnológicas, realocação de recursos, treinamento da força de trabalho, alterações nos métodos de circulação e venda de mercadorias, etc. O objetivo era o aumento dos lucros, possibilitando maior rapidez no pagamento da dívida externa.

A atuação da OPDA na produção de tabaco e seda exemplifica bem o ponto ao qual chegou a ingerência externa. No setor do tabaco, a OPDA criou, em maio de 1883, a Société de la Régie Coniterésée des tabacs de l'Empire ottoman, com a tarefa de estimular as seções 
da indústria e da agricultura para aumentar a arrecadação. A Régie direcionou a produção para a exportação, montou fábricas de cigarros sobre gerência de estrangeiros e reorganizou o cultivo de modo que essa atividade se concentrasse na mão de poucos cultivadores, tirando do circuito aqueles que não conseguiam se encaixar nas novas regulações ou pagar as taxas de licença (CHOTZIDIS, s/d; BIRDAL, 2010). Também foram formadas unidades de combate ao roubo e contrabando de tabaco, as kolcus, conhecidas por sua extrema brutalidade no contato com suspeitos de contrabando (BIRDAL, 2010). No setor da seda, a OPDA se encarregou de importar da França e da Itália ovos de bicho da seda amarelo, criou programas para treinar os trabalhadores na execução do avançado método de Pasteur, incentivou o cultivo de amoreiras, cujas folhas servem de alimento para o bicho da seda, e montou laboratórios modernos para controle de sementes (CHOTZIDIS, s/d).

\section{Considerações finais}

A subsunção do governo otomano a interesses políticos e econômicos externos foi parte integrante da expansão mundial das capacidades e ações de setores das classes dominantes europeias, que, concomitantemente à entrada no Império Otomano, também intensificavam sua presença especialmente nas regiões ocidentais da África e no subcontinente indiano (WALLERSTEIN, 2011). Nesse ponto, a visão de Wallerstein se alinha às leituras dos teóricos do sistema-mundo em particular e dos estudiosos que se colocam como marxistas ou tributários do marxismo em geral. Essa tradição costuma trabalhar com uma grande narrativa, geralmente iniciada em fins do século $\mathrm{XV}$, que traça a ascensão e expansão do modo de produção capitalista e da cultura ocidental em detrimento dos povos africanos, asiáticos e americanos.

Por meio de uma breve revisão bibliográfica, procuramos resgatar como se deu a dominação financeira do Império Otomano por parte de grupos capitalistas europeus, em uma época na qual as organizações financeiras se tornavam proeminentes. Evidentemente, o processo de dominação foi muito mais complexo do que a tomada de controle direto, por estrangeiros, das principais fontes de renda do sultanato, envolvendo outros processos econômicos, culturais, políticos, diplomáticos e militares. Sem descartar a narrativa da expansão do capitalismo, tivemos a intenção de salientar o elemento humano desse processo, elemento central para pensarmos a História, como diz Bloch (2015), e também Thompson (sd, sp), que afirma, na esteira do Dezoito Brumário de Luís Bonaparte de Marx: “[...] olhemos a história de fato como história - homens colocados em contextos reais que eles não 
escolheram, e confrontados por forças incontornáveis, com o peso imediato de relações e deveres e com uma escassa oportunidade para inserir sua própria agência".

Por mais que a agência de homens específicos seja balizada pelas mais diversas pressões do meio social de que são partícipes, essa ação não deixa de ser menos real. Um estudo razoavelmente aprofundado do Império Otomano na segunda metade do século XIX mostra claramente que, enfrentando diversos problemas internos - dos quais uma das consequências foi a descentralização da autoridade — a cúpula do sultanato elaborou um plano de recuperação da centralidade do poder em Constantinopla. Frente à necessidade de recursos para a empreitada, o governo procurou voluntariamente empréstimos estrangeiros. Pode-se discutir se existiram de fato outras opções, dado o descalabro financeiro no qual se encontrava o Império Otomano. Mas o fato é que seus líderes tiveram agência no aumento da influência de grupos financeiros externos em seu império, inclusive procurando meios para torná-lo atrativo para investimentos. Em vez de apenas um movimento - a expansão do capitalismo - se objetivando sobre formações sociais passivas, temos vários projetos, dos quais destacamos os planos de reestruturação do Império Otomano e a necessidade de investir capital por parte de grupos europeus; planos que durante as últimas décadas século XIX entraram em simbiose, com a eventual e definitiva derrota do projeto otomano após o desfecho da Primeira Guerra Mundial.

Todavia, também é insuficiente considerar apenas dois projetos ativos em interação. Nossos estudos mostraram que o processo foi composto pelo choque de muitos projetos diversos e mesmo colidentes, tanto entre os otomanos quanto entre os europeus. No caso da OPDA, por exemplo, Birdal diz que ela é geralmente retratada na literatura como

[...] simplesmente um agente oficial de potências estrangeiras ou do capitalismo ocidental. Essa perspectiva coloca o capitalismo ocidental como uma entidade monolítica e passa por cima do fato de que diferentes grupos capitalistas, muitas vezes dentro dos mesmos países de origem, tinham interesses conflitantes em vários pontos. Membros da OPDA eram diretamente nomeados pelas organizações de acionistas de seus respectivos países. Logo, eles eram responsáveis por todos os acionistas. Esses representantes estavam sem dúvida sobre a influência de seus governos [...]. Mas em muitas ocasiões, eles também se opuseram à política geral de seus governos para proteger os interesses dos acionistas, que estavam intimamente ligados à performance da economia Otomana. Por exemplo, enquanto mercadores estrangeiros pressionavam por menores tarifas para produtos europeus e a extensão dos privilégios fiscais garantidos aos estrangeiros, a OPDA buscava o protecionismo e a abolição dos privilégios fiscais. Em alguns casos, as imposições das potências estrangeiras causaram sérias restrições às atividades da OPDA. (BIRDAL, 2010, pp.174/175).

Dentro do Império Otomano, os Banqueiros de Gálata, ainda que estivessem baseados em Constantinopla e fossem compostos por súditos imperiais, de modo algum podemos dizer 
que seus objetivos eram os mesmos de seu governo. Seu projeto se assemelhava muito mais ao dos capitalistas europeus, embora não raro rivalizassem com estes: utilizaram os planos de recentralização otomana para, por meio de empréstimos a juros altos, acumular capital à custa do sultanato. Dadas as suas ações e sua capilaridade no circuito financeiro europeu, avaliamos que considerar os Banqueiros de Gálata um grupo periférico ou subordinado seria, no mínimo, problemático.

O que ficou evidente é que o caso do Império Otomano, assim como qualquer caso estudado com profundidade razoável, desafia a lógica de pensamento baseada em oposições da espécie centro/periferia ou imperialismo/países dominados, muito comuns nas narrativas da ascensão ocidental. Como já dissemos, não acreditamos que o grande arco da expansão do capitalismo deva ser descartado - ao contrário, é essencial para entendermos vários processos da contemporaneidade —, mas sim, problematizados. Avaliamos que essas categorias são úteis quando lidamos com perspectivas geograficamente amplas e de longa duração, mas se mostram insuficientes quando lidamos com recortes mais específicos, posto a tendência em escamotear dados empíricos importantes e, principalmente, a agência humana como núcleo do processo histórico.

\section{Notas}

\footnotetext{
${ }^{1}$ O quediva era o governador do Egito, submetido ao sultão de Constantinopla. Em 1854, Ibrahim Paxá ocupava esse cargo.

${ }^{2}$ Bank of England, o banco central da Inglaterra, fundado em 1694.

${ }^{3}$ Chamamos atenção para a seguinte passagem do clássico Apologia da história ou o ofício do historiador: "Há muito tempo, nossos grandes precursores, Michelet, Fustel de Coulanges, nos ensinaram a reconhecer: o objeto da história é, por natureza, o homem. Digamos melhor: os homens. Mais que o singular, favorável à abstração, o plural, que é o modo gramatical da relatividade, convém a uma ciência da diversidade. Por traz dos grandes vestígios sensíveis da paisagem [...], por trás dos escritos aparentemente mais insípidos e as instituições aparentemente mais desligadas daqueles que as criaram, são os homens que a história quer capturar." (BLOCH, 2015, p.54).

${ }^{4}$ As classes dominadas no Império Otomano - em especial os camponeses - , que mais tiveram seu cotidiano afetado pelos processos que abordaremos, não receberão aqui mais do que menções circunstanciais, posto que nosso foco principal são alguns aspectos das relações entre membros das classes dominantes otomanas com suas contrapartes europeias.

${ }^{5}$ As terras nas áreas urbanas eram geralmente de propriedade de fundações de caridade controladas por instituições religiosas (PALMER, 2014).

${ }^{6} \mathrm{O}$ sultanato agia com notável conservadorismo técnico, o que em parte contribuiu para a crescente defasagem tecnológica entre o Império e a Europa Ocidental, especialmente a partir de fins do século XVIII.

${ }^{7}$ Um dos motivos pelos quais o regulamento otomano não permitia o lucro e a acumulação ilimitados era o objetivo de impedir que os súditos amealhassem um poder econômico capaz de ameaçar o poder dos Oslamilar. Mas é interessante notar que isso também se deve ao fato de que o Islã desaprova o lucro desmedido. Ao contrário das sociedades ditas ocidentais, não há separação oficial entre assuntos políticos/estatais e questões religiosas (ainda que o Império Otomano tenha sido o primeiro sistema político muçulmano a contar, em seu interior, com uma hierarquia especificamente religiosa, análogas, grosso modo, às igrejas cristãs) (ANDERSON, 1974).
} 


\begin{abstract}
${ }^{8}$ De acordo com o regulamento otomano, artesãos que vendiam seus próprios produtos e pequenos comerciantes não eram considerados mercadores (INALCIK, 1969).

${ }^{9}$ Entre os mercadores e especuladores havia considerável número de gregos, armênios e judeus. Os últimos foram estimulados a se estabelecer no Império Otomano especialmente após a expulsão dos judeus sefarditas da Península Ibérica no final do século XVI. O sultanato calculava que os recursos e as habilidades comerciais dos judeus seriam úteis para o Império (INALCIK, 1969).

${ }^{10}$ Também conhecido como Anglo-Turkish Commercial Contention (ATCG).

${ }^{11}$ À primeira vista, parece desprovido de sentido que o governo otomano contribua para o enfraquecimento de seus próprios monopólios. Todavia, faz parte do contexto de Balta Liman a ascensão de Mohammed Ali como governador do Egito, à época uma província otomana. Embora não tenha planejado de fato romper com Constantinopla, Ali buscou conduzir um governo relativamente autônomo, centrado em um projeto de desenvolvimento econômico no Egito inspirado nas experiências europeias, em especial francesas. Para tanto, Ali criou seus próprios monopólios comerciais, com o intuito de proteger a produção egípcia da concorrência interna. O sultanato via o acordo Balta Liman com bons olhos em parte porque calculou que o principal prejudicado seria Ali, um súdito que não apenas não respeitava a autoridade de Constantinopla, como também poderia se transformar em um exemplo a ser alastrado pelo Império.

12 Assim chamados por operarem a partir do distrito de Gálata, o centro financeiro de Constantinopla, os banqueiros de Gálata eram geralmente de origem grega, judaica, armênia e levantina.

${ }^{13} \mathrm{Na}$ Europa, eram conhecidos como "os vampiros de Gálata".

${ }^{14}$ Rumélia era o nome pelo qual era conhecida a região dos Balcãs.

${ }^{15}$ Um trecho do decreto de Gülhane: "Todo mundo sabe que, desde os primeiros dias do Estado otomano, os altos princípios do Corão e as leis da charia sempre foram perfeitamente preservados. Nosso poderoso Sultanato alcançou o mais alto grau de força e poder, e todos os seus súditos de comodidade e prosperidade. Mas nos últimos 150 anos, devido a uma sucessão de causas difíceis e diversas, a sagrada charia não foi obedecida nem as benéficas regras seguidas; consequentemente, sua antiga força e prosperidade transformaram-se em fraqueza e pobreza. É evidente que os países não governados pela charia não podem sobreviver [...]. Cheios de confiança na ajuda do Altíssimo, e certos do apoio de nosso Profeta, julgamos necessário e importante introduzir de agora em diante uma nova legislação para conseguir administração efetiva do governo e províncias muçulmanas." (apud HOURANI, 2006, p.359).

16 “"...] o excedente anual que assim clamava por ser investido era estimado em 60 milhões de libras, ou quase o dobro do valor estimado do capital total da indústria algodoeira na década de 1830. A economia simplesmente não tinha como absorver um investimento industrial dessa magnitude, e na verdade a crescente disposição de empresários calculistas em meter as mãos nos bolsos para fazer despesas em nada lucrativas (como por exemplo, os gigantescos, medonhos e caríssimos edifícios de prefeituras que as cidades do norte começaram a usar como armas em suas guerras de rivalidades, depois de 1848) atesta não só uma crescente riqueza, como também suas poupanças cada vez maiores, em excesso ao que as indústrias locais necessitavam para reinvestimento." (HOBSBAWM, 2014, p.103).

${ }^{17}$ Regiões que hoje fazem parte da Romênia.

${ }^{18}$ O Grão Vizir era o segundo posto governamental mais alto do Império Otomano, abaixo apenas do sultão, que nomeava os grãos vizires e detinha, sozinho, o poder de depô-los.

${ }^{19}$ Para esse período, Hourani (2006) considera uma libra turca equivalente a 0,9 libra esterlina.
\end{abstract}

\title{
Referências bibliográficas
}

AL, H. Debt and the Public Debt Administration. In: AGOSTON, G.; MASTERS, B. A. (org). Encyclopedia of the Ottoman Empire. Primeira edição. New York: Info Base Publishing, 2009, 689p.

ANDERSON, P. Lineages of the absolutist state. Primeira edição. London: New Left Books, 1974, 590p.

BIRDAL, M. The political economy of the Ottoman public debt: Insolvency and european financial control in the late nineteen century. Primeira edição. New York: I. B. Tauris, 2010, 254p.

BLOCH, M. Apologia da história ou o ofício do historiador. Tradução: André Telles. Primeira Edição. Rio de Janeiro: Zahar, 2015, 159p. 
CHOTZIDIS, A. A. The Impact of the Ottoman Public Debt Administration on the Economies of Epirus, Macedonia and Thrace (1881-1912): A Preliminary Approach. Tessalônica: Departamento de História e Arqueologia da Universidade Aristóteles, s/d, 20p. Disponível em:

http://www.lse.ac.uk/europeanInstitute/research/hellenicObservatory/pdf/4th_\%20Symposiu m/PAPERS_PPS/HISTORY\%20I/CHOTZIDIS.pdf. Acesso em 02/03/2017.

ELDEM, E. Ottoman financial integration with Europe: Foreign loans, the Ottoman Bank and the Ottoman public debt. European Review: Interdisciplinary journal of the Academia Europaea. Cambridge: Cambridge University Press, vol. 3, nº13, 2005, p.431-445.

HANIOĞLU, M. S. A brief history of the late Ottoman Empire. Primeira Edição. Princenton: Princenton University Press, 2008, 249p.

HOBSBAWM, E. Da revolução industrial inglesa ao imperialismo. Tradução: Donaldson Magalhães Garschagen. Sexta edição. São Paulo: Forense Universitária, 2014, 350p.

A era dos impérios (1875-1914). Tradução: Sieni Maria Campos e Yolanda

Steidel de Toledo. Décima edição. Rio de Janeiro: Paz e Terra, 2006. 346p.

HOURANI, A. Uma história dos povos árabes. Tradução: Marcos Santarrita. Primeira edição. São Paulo: Companhia das Letras, 2006, 704p.

INALCIK, H. Capital formation in the Ottoman Empire. The journal of economic history. Cambridge: Cambridge University Press, vol.29, nº1, 1969, p.97-140.

KIERNAN, V. G. European empires from conquest to collapse, 1815-1960. Primeira edição. Leicester: Leicester University Press, 1982.

. The lords of human kind: black man, yellow man and white man in na age of empire. Primeira edição. Boston: Little, Brown and Company, 1969.

LESSA, A. C. História das relações internacionais: a Pax Britannica e o mundo do século XIX. Primeira edição. Petrópolis: Vozes, 2005, 168p.

LEWIS, B. A descoberta da Europa pelo Islã. Tradução: Maria Clara Cescato. Primeira edição. São Paulo: Perspectiva, 2010.

OWEN, R. The Middle East in the World Economy 1800-1914. Primeira edição. New York: I. B. Tauris, 2005, 387p.

OZEKICIOGLU, S; OZEKICIOGLU, H. First borrowing period at Ottoman Empire (18541876): Budget policies and consequences. BEH - Business and Economic Horizons. Prague: Prague Development Center, vol.3, n³, 2010, p.28-46.

PALMER, A. Declínio e queda do Império Otomano. Tradução: Glauber Vieira. Primeira edição. Rio de Janeiro: Globo, 2014, 317p.

PANIKKAR, K. M. A dominação ocidental na Ásia. Tradução: Nemésio Salles. Segunda edição. São Paulo: Saga, 1969.

QUATAERT, D. The Ottoman Empire 1700-1922. Segunda edição. Cambridge: Cambridge University Press, 2005, 287p.

THOMPSON, E. P. The peculiarities of the english. S/d, s/p. Disponível em: https://www.marxists.org/archive/thompson-ep/1965/english.htm. Acesso em 10/03/2017.

WALLERSTEIN, I.; DECDELÍ, H; KASAB, R. The incorporation of the Ottoman Empire into the world-economy. In: ISLAMOGLINAN, H. (org.). The Ottoman Empire and the world-economy. Primeira edição. Cambridge: Cambridge University Press; Paris: Éditions de la Maison des Sciences de l'Homme, 2004, 485p.

WALLERSTEIN, I. The Modern World-System III: The Second Era of Great Expansion of the Capitalist World-Economy, 1730s-1840s. Primeira edição. Los Angeles: University of California Press, 2011, 390p.

WOLF, E. A Europa e os povos sem história. Tradução: Carlos Eugênio Marcondes de Moura. Primeira edição. São Paulo: Edusp, 2009, 608p. 